JUSTYNA MROZEK

Uniwersytet im. Adama Mickiewicza

w Poznaniu

\title{
DZIECI - IDEOLOGIA - INDOKTRYNACJA. CZASOPISMO „PLOMYCZEK" W OKRESIE II RZECZYPOSPOLITEJ, PRL I III RP
}

\begin{abstract}
AвSTRACt. Mrozek Justyna, Dzieci - ideologia - indoktrynacja. Czasopismo "Płomyczek” w okresie II Rzeczypospolitej, PRL i III RP [Children - Ideology - Indoctrination. Płomyczek Magazine in the Second Polish Republic, the Polish People's Republic and the Third Polish Republic]. Studia Edukacyjne nr 52, 2019, Poznań 2019, pp. 303-315. Adam Mickiewicz University Press. ISSN 1233-6688. DOI: 10.14746/ se.2019.52.20
\end{abstract}

The main purpose of this article is to answer the following questions: did the current sociopolitical situation determine the contents of kid's Płomyczek magazine and if so, how. These questions suggest a hidden agenda of the periodical as a tool of indoctrination. The study was conducted on issues of Ptomyczek from the period of the Second Polish Republic, the Polish People's Republic and the Third Polish Republic. The research shows similarities between the ideology in the said period and the content of Ptomyczek, however indoctrination took place only during the Second Polish Republic and the Polish People's Republic. Issues from the Third Polish Republic, unlike the earlier ones, criticized current politicians and stimulated reflective thinking.

Key words: kid's magazine, Płomyczek, ideology, indoctrination

\section{Wprowadzenie}

Ideologia, jako system wyznawanych przez daną grupę poglądów, buduje ludzką wspólnotę idei i celów oraz tworzy przekonanie, że istnieje pewien społeczny konsensus odnośnie wyznawanych wartości. Każdy światopogląd zakłada istnienie idealnego obywatela, który może nabrać rzeczywistych kształtów dzięki odpowiednio poprowadzonej edukacji. Instytucje edukacyjne, za sprawą oficjalnego programu nauczania, jak i specyficznego środowiska (ukrytego programu nauczania) kształtują nasz pogląd na świat i nas samych. Wpajane są nam określone przekonania społeczne, 
polityczne i ekonomiczne, co sprawia, że łatwiej utrzymać obywateli w ryzach. Ideologia bowiem wykorzystywana jest także, by usprawiedliwić i usankcjonować pewien układ sił w społeczeństwie (np. po dojściu nazistów do władzy, prawa do edukacji odmówiono m.in. Żydom i socjaldemokratom). Jak zauważył G. Gutek, przed okresem oświecenia wychowanie służyło indoktrynacji, wpajając przekonanie o nienaruszalności obowiązującego ładu społecznego ${ }^{1}$. Z kolei N. Chomsky doszedł do podobnych refleksji, analizując współczesny system edukacyjny w Stanach Zjednoczonych. $W$ jego opinii, edukacja jest narzędziem $w$ rękach rządzących do utrzymania społeczeństwa w uległości. Demokratyczny kraj, jakim są Stany Zjednoczone, przyjmuje jedynie fasadę demokratyczności, bowiem w rzeczywistości władza, sprawowana przez nieliczną elitę, jest niezależna od obywateli. N. Chomsky przyrównuje szkołę do redakcji gazety i biura prasowego rządu, gdyż, jego zdaniem, instytucje te tworzą iluzje i indoktrynują, choć czynią to dużo subtelniej w porównaniu z krajami totalitarnymi. Edukację w swojej ojczyźnie nazywa "oswajającą". Dostosowuje ona jednostki do doktryn i praktyk pożądanych przez rządzących, zabijając tym samym w uczniach samodzielne myślenie, obywatelską inicjatywę, krytycyzm i odpowiedzialność. Edukacja oswajająca przygotowuje obywateli do zajęcia z góry określonych miejsc w strukturze społecznej, uzasadniając ten proces adaptacji odpowiednią ideologią ${ }^{2}$.

B. Nowicka-Watrak zauważa, że wszystkie systemy totalitarne koncentrują swe zainteresowania wokół dziedziny wychowania tak, by służyło ono ich interesom ${ }^{3}$. Osiągnięcie tego celu ułatwia im indoktrynacja. Warto w tym miejscu odwołać się do samego pojęcia indoktrynacji Leksykonu PWN, który ujmuje ją jako:

proces wpajania członkom społeczeństwa przekonań, zwłaszcza politycznych i spolecznych, leżących w interesie grup rządzących, za pomocą uporczywej propagandy prowadzonej przez środki masowego przekazu czy systemu oświaty

Ch. Tan przedstawia cztery kryteria, pozwalające na uznanie pewnych zabiegów za indoktrynację. Kryterium zawartości wskazuje na obecność przekonań lub doktryn pozbawionych podstaw wiarygodności. Kryterium intencji odnosi się do sytuacji, których celem jest stłamszenie krytycyzmu i skłonienie człowieka lub grupy ludzi do przyjęcia pewnych myśli bez uza-

\footnotetext{
${ }^{1}$ G.L. Gutek, Filozoficzne i ideologiczne podstawy edukacji, Gdańsk 2003, s. 142-154.

2 N. Chomsky, Chomsky on MisEducation, Lanham 2004, s. 15-28.

${ }^{3}$ B. Nowicka-Watrak, Wychowanie to manipulowanie człowiekiem, Edukacja i Dialog, 2003, 1, s. 19.

${ }^{4}$ Indoktrynacja, [w:] Pedagogika. Leksykon PWN, red. B. Milerski, B. Śliwerski, Warszawa 2000, s. 84 .
} 
sadnienia. Trzecie kryterium skupia się na metodzie, za sprawą której proces indoktrynacji obejmuje akceptację pewnych poglądów bez dostatecznych informacji bądź irracjonalnie bez dowodów. Wreszcie kryterium czwarte koncentruje się na rezultacie - do indoktrynacji dochodzi, jeśli człowiek, w wyniku pewnych zewnętrznych działań, posiada poglądy odporne na przeczące im dowody. Ch. Tan zaznacza, że choć powyższe kryteria zawodzą w niektórych przypadkach, to warto zauważyć, że wszystkie wskazują na brak racjonalnego uzasadnienia lub dowodów jako charakterystycznych cech indoktrynacji ${ }^{5}$.

Celem artykułu jest ukazanie praktyk indoktrynacyjnych zawartych w polskim czasopiśmie „Płomyczek” w trzech okresach historii Polski: II Rzeczpospolitej, Polski Ludowej i III Rzeczpospolitej. Istotą pracy są rozważania dotyczące ideowego oblicza pisemka, zmieniającego się na przestrzeni dekad. W artykule analizowane są przykładowe strony czasopisma, odnoszące się do sposobów prezentowania młodym czytelnikom rzeczywistości społeczno-politycznej Polski.

\section{Problem: procesy indoktrynacji w czasopiśmie - analiza wybranych treści}

Wydawany w latach 1927-2012 „Płomyczek” był świadkiem trzech okresów w historii naszego kraju; nie był to bynajmniej świadek niemy, lecz komentujący i wpisujący się $\mathrm{w}$ dominującą aktualnie $\mathrm{w}$ państwie ideologię. Pierwszy numer czasopisma ukazał się po zamachu majowym z 1926 roku, obalającym rządy prawicy parlamentarnej, w wyniku którego władza w kraju skupiła się w rękach Józefa Piłsudskiego i jego obozu, zwanego sanacją. Od tego momentu rozpoczęło się wypracowywanie teoretycznych i ustawowych podstaw wychowania państwowego ${ }^{6}$. Jednym z apologetów tej idei był Adam Skwarczyński - oficer legionowy, nauczyciel i publicysta. W swoich pracach nawoływał do uwzględnienia $\mathrm{w}$ procesie kształtowania młodego pokolenia Polaków następujących wytycznych: gloryfikowania działalności legionów, zapoznawania z pozytywnymi osiągnięciami sanacyjnego rządu, wdrażania do pracy ekonomicznej i społecznej na rzecz państwa oraz krzewienia kultu marszałka ${ }^{7}$. Na początkowym etapie edukacji zabiegano o wykształcenie

\footnotetext{
s. 1-3.

${ }^{6}$ K. Jakubiak, Wychowanie państwowe jako ideologia wychowawcza sanacji, Bydgoszcz 1994, s. 44.

${ }^{7}$ K. Trzebiatowski, Szkolnictwo powszechne w Polsce w latach 1918-1932, Wrocław 1970, s. 285-286.
}

${ }^{5}$ Ch. Tan, Teaching without indoctrination: implications for values education, Rotterdam 2008, 
u uczniów szacunku dla portretów marszałka oraz prezydenta I. Mościckiego. Prezentowano wiersze i pieśni nawiązujące do legionów.

Sprzymierzeńcem sanacji w propagowaniu jej koncepcji wychowawczej był Związek Polskiego Nauczycielstwa Szkół Powszechnych. Nic więc dziwnego, że czasopisma dziecięce, wydawane pod patronatem Związku, stały się nośnikiem wychowania państwowego, a do nich należał właśnie „Płomyczek” ${ }^{8}$. Jego okładka z lutego 1935 roku przedstawia, zapewne typową dla okresu międzywojennego, salę szkolną, gdzie tuż przy tablicy, czyli w miejscu absorbującym uwagę uczniów, zawieszone są dwa portrety9. Widnieją na nich kluczowe postacie sanacyjnej Polski - marszałek Piłsudski oraz prezydent Ignacy Mościcki. To właśnie ci dwaj politycy byli zdecydowanie najczęstszymi, spośród przedstawicieli władzy, bohaterami „płomyczkowych" tekstów i ilustracji. Niniejsza okładka jest również kwintesencją wychowania państwowego: znajdują sią na niej krzyż - znak chrześcijaństwa, biało-czerwone chorągiewki oraz wizerunki najważniejszych osób w kraju jako symbole polskiego narodu i państwowości.

Postać J. Piłsudskiego była obecna na kartkach „Płomyczka” aż do ostatnich przedwojennych numerów. Wiersz "Polska w żałobie” pochodzi z egzemplarza wydanego 20 maja 1935 roku, obwieszczającego dzieciom śmierć marszałka ${ }^{10}$. Żałobny nastrój znamionuje kolor okalającej utwór winiety, a cały numer czasopisma wydrukowano jedynie z użyciem ciemnych barw. Tytuł wiersza wyraża wielką wagę zmarłego dla kraju. W jego świetle Piłsudski przedstawiany jest jako wyzwoliciel ojczyzny i jej dobrodziej, choć obraz „chwalebnej” sytuacji Polski pozostaje w sprzeczności z kryzysem gospodarczym, dręczącym kraj od 1929 roku $^{11}$. Z utworu bije niedowierzanie i głęboka rozpacz, tłumaczona zarówno ogromnymi zasługami marszałka dla ojczyzny, jak i niezwykłymi cechami jego charakteru. Wiersz jest typowym, pośmiertnym panegirykiem, wychwalającym zmarłego i jego czyny. Utwór wieńczy przysięga, składana przez wiernych marszałkowi żołnierzy i dzieci, odnosząca się do deklaracji kroczenia śladem Naczelnego Wodza.

„Płomyczek” ukazywał się także podczas II wojny światowej, lecz poza granicami kraju. Jako dodatek do moskiewskich "Nowych Widnokręgów”, uzupełniał podręczniki szkolne polskich dzieci w ZSRR ${ }^{12}$. Pierwszy powojenny egzemplarz „Płomyczka” ujrzał światło dzienne 1 lipca 1945 roku $^{13}$.

${ }^{8}$ I. Michalska, Czasopisma Związku Nauczycielstwa Polskiego dla dzieci w okresie Drugiej Rzeczypospolitej, Łódź 1994, s. 15.

${ }^{9}$ Zob. okładka "Płomyczka” 1935, nr 23, s. 361.

${ }^{10}$ Polska w żatobie, „Płomyczek” 1935, nr 36, s. 146.

${ }_{11}$ R. Śniegocki, Historia. Burzliwy wiek XX, Warszawa 2006, s. 55.

12 S. Aleksandrzak, Działalność wydawnicza Zwiazku Nauczycielstwa Polskiego, Przegląd Historyczno-Oświatowy, 1974, 1, s. 32-33.

${ }_{13}$ M. Rogoż, Czasopisma dla dzieci i młodzieży Instytutu Wydawniczego "Nasza Księgarnia” w latach 1945-1989, Kraków 2009, s. 74. 

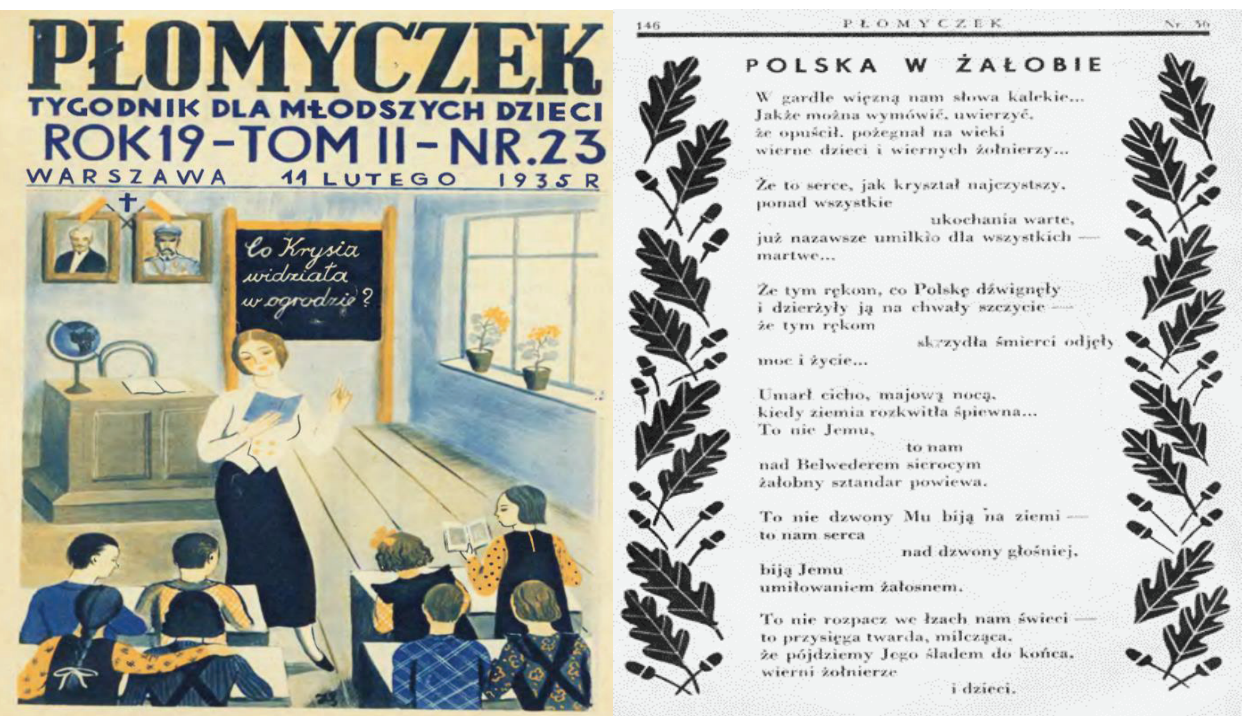

Ryc. 1. Okładka przedstawiająca klasę szkolną, w tle portrety I. Mościckiego i J. Piłsudskiego (fot. 1) oraz pośmiertny panegiryk dla J. Piłsudskiego (fot. 2)

Źródło: „Płomyczek” 1935, nr 23, s. 361 (fot. 1), „Płomyczek” 1935, nr 36, s. 146 (fot. 2)

Początkowo jego treść nie różniła się od prezentowanej w dwudziestoleciu międzywojennym. Na łamach czasopisma nie uwzględniano jeszcze polityków związanych z nowym kształtem państwa i ich ideologii. Ponadto, redakcja czasopisma respektowała kalendarz liturgiczny, działając zgodnie z dyrektywami ówczesnych władz. Tuż po wojnie rządzący postanowili bowiem uśpić czujność rodziców, pozostawiając w instrukcjach dla szkół przedwojenne wychowanie w miłości do Boga ${ }^{14}$. Jednak z początkiem 1948 roku z „płomyczkowych" kart znikają, obecne jeszcze przed II wojną, święta Wielkanocy i Bożego Narodzenia ${ }^{15}$. Periodyk porzuca wątki religijne, eksponując nowe święta państwowe i rocznice, jak między innymi 12 października (Dzień Ludowego Wojska Polskiego), 7 listopada (rocznica wybuchu Rewolucji Październikowej), 1 maja (Święto Pracy), 9 maja (Dzień Zwycięstwa), 22 lipca (Święto Odrodzenia Polski $)^{16}$. Od tej pory dokładano starań, aby światopogląd naukowy zastąpił religijną wizję świata. Utrwalone w polskiej tradycji chrześcijańskie święta odzierano z ich sakralnego wymiaru. Nacisk kładziono na towarzyszące im

${ }^{14}$ S. Bober, Walka o dusze dzieci i mtodzieży w pierwszym dwudziestoleciu Polski Ludowej, Lublin 2011, s. 66.

${ }^{15}$ B. Olszewska, Techniki ideologicznej indoktrynacji w wybranych utworach realizmu socjalistycznego publikowanych w "Płomyczku”, Kwartalnik Opolski, 2008, 2/3, s. 113.

${ }^{16}$ B. Olszewska, Literatura na tamach "Płomyczka" (1945-1980), Opole 1996, s. 102-103. 
zwyczaje, unikając ich religijnej podbudowy. Wymowna jest okładka z 1950 $\mathrm{roku}^{17}$. Na pierwszym planie widoczna jest choinka, stojąca $\mathrm{w}$ świetlicowym pomieszczeniu. $Z$ pewnością umieszczona na szczycie drzewka czerwona gwiazda - komunistyczny symbol, nie jest tu elementem przypadkowym. To właśnie pod nazwą "choinka” („choinka noworoczna”) egzystować miało w przestrzeni publicznej Boże Narodzenie. Wracając do strony tytułowej „Płomyczka", w tle zauważyć można portret ówczesnego prezydenta, Bolesława Bieruta. W ten sposób świetnie pokazano ówcześnie rozkładające się akcenty: polityka - dziedzina ludzka, zdegradowała religię - sferę nadprzyrodzoną. Kult należał się odtąd nie istotom boskim, lecz dzierżącym władzę jednostkom ludzkim. Dopiero w latach osiemdziesiątych grudniowe święta odzyskały na stronach czasopisma swój chrześcijański wymiar.
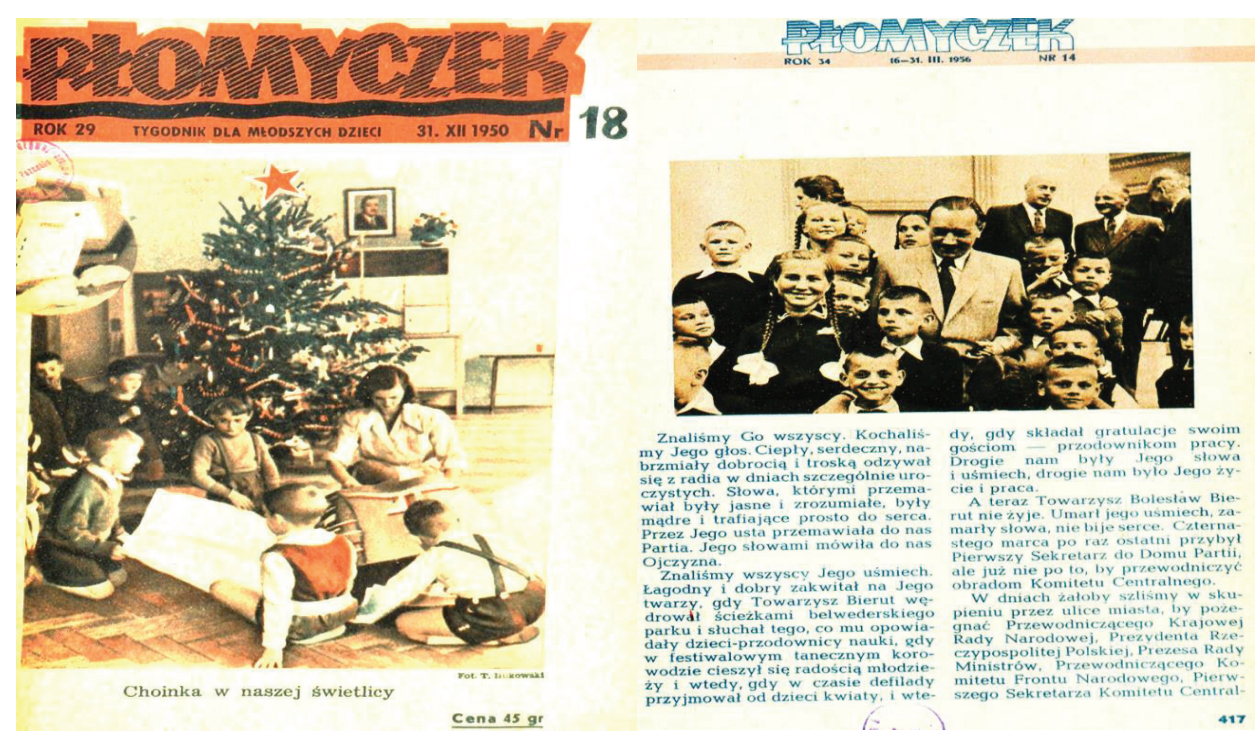

Ryc. 2. Okładka prezentująca świecką wersję Bożego Narodzenia w tle portret B. Bieruta (fot. 3) oraz artykuł poświęcony zmarłemu B. Bierutowi (fot. 4)

Źródło: „Płomyczek” 1950, nr 18, s. 269 (fot. 3), „Płomyczek” 1956, nr 14, s. 417 (fot. 4)

Do 1955 roku redakcja pisemka opublikowała kilka utworów poświęconych Stalinowi, Leninowi i Bierutowi. Pisane w konwencji hagiograficznej, wychwalały ich zdolności przywódcze, ofiarność i uczciwość, a także kreowały ich na wielkich przyjaciół dzieci, co wzmacniano potwierdzającymi to fotografiami. PRL-owski „Płomyczek” nie stronił od świata polityki i jego przedstawicieli, kreując część z nich, za pomocą kłamstwa i „prawdy niepełnej”, na

17 Okładka „Płomyczka” 1950, nr 18, s. 269. 
autorytety. Pomocna była w tym zadaniu między innymi funkcja magiczna języka, by z użyciem słów wykreować korzystną dla władzy rzeczywistość ${ }^{18}$. Na czytelników nie oddziaływano dowodami, lecz emocjami. B. Śliwerski zauważa, że ideologie jako wyrazicielki interesów pewnych grup nie odnoszą się do logicznego rozumowania, lecz właśnie do emocji, osobistych postaw i wartości. Dlatego, posługują się stwierdzeniami, które sprawiają wrażenie niezagrażających odbiorcy, a jednocześnie podważających stanowisko konkurencji ${ }^{19}$. Podobnie było w przypadku artykułu, który ukazał się po śmierci prezydenta Bolesława Bieruta w numerze z 16 marca 1956 roku. W większości na jego treść składają się pochwalne zdania, kierowane pod adresem zmarłego. Jego osoba poddana została hiperbolizacji - oto niektóre z przypisywanych mu w tekście przymiotów: „ciepły, serdeczny głos, jasne i zrozumiałe słowa, łagodny i dobry uśmiech, skromność, siła woli. Bierut prezentowany jest dzieciom jako przykład i wzór, skromny człowiek, którego siła woli i przekonań była mocniejsza od sanacyjnej". Celowo przemilczano natomiast niewygodne dla władzy informacje o jego szpiegostwie na zlecenie ZSSR oraz odpowiedzialności za zbrodnie i terror na polskich obywatelach. Autor tekstu wkłada dzieciom w usta następujące zdanie: „W naszej pracy szkolnej i harcerskiej, będziemy się starali, postępować tak, jak On sobie tego życzył, jak sobie tego życzy Partia"20.

W Polsce Ludowej w każdym najmniejszym dziecku władza widziała obywatela, którego możliwie najwcześniej należy wprowadzać w aktualne zagadnienia społeczno-polityczne i gospodarcze ojczyzny ${ }^{21}$. Bolesław Bierut wielokrotnie apelował o zaznajamianie każdego Polaka, bez względu na wiek, z programem budownictwa socjalistycznego. Zapoznawanie wychowanków z sytuacją ekonomiczną i produkcyjną państwa, zwane politechnizacją, miało za zadanie przygotować młode pokolenie do funkcjonowania $\mathrm{w}$ ramach socjalistycznej gospodarki ${ }^{22}$. Jedna $\mathrm{z}$ największych akcji propagandowych omawianego okresu dotyczyła planu sześcioletniego. Nowy program gospodarczy miał stać się dla młodych ludzi na tyle bliski, by zechcieli włączyć się w jego realizację $e^{23}$. W 1950 roku czasopismo opublikowało piosenkę, której

${ }_{18}$ D. Podlawska, I. Płóciennik, Nowomowa, [w:] Słownik wiedzy o języku, Bielsko-Biała 2006, s. 191.

19 B. Śliwerski, Program wychowawczy szkoły, Warszawa 2001, s. 74.

${ }^{20}$ Cytaty pochodzą z artykułu poświęconego zmarłemu B. Bierutowi, „Płomyczek” 1956, nr 14 , s. 417.

21 E. Magiera, Wychowanie morskie na tamach "Płomyczka" i „Płomyka” w Polsce Ludowej, [w:] Oświata, wychowanie i kultura fizyczna w rzeczywistości społeczno-politycznej Polski Ludowej (19451989), red. R. Grzybowski, Torun 2004, s. 245.

22 S. Bober, Walka o dusze dzieci i młodzieży, s. 229-231.

23 M. Brodala, Propaganda dla najmłodszych w latach 1948-1956. Instrument stalinowskiego wychowania, [w:] Przebudować człowieka. Komunistyczne wysiłki zmiany mentalności, red. M. Kula, Warszawa 2001, s. 62-64. 
fragment brzmi następująco: „Polsce trzeba więcej stali! Polsce trzeba więcej hut! Naprzód! Szybciej! Więcej! Dalej! Sześcioletni rośnie trud! Pomożemy z całych sił, żeby Plan na czas był!"24.

Początkowo zmiany, jakie zachodziły w Polsce od 1989 roku nie znajdowały swojego odzwierciedlenia na kartkach „Płomyczka” (np. nie znaleziono wzmianek na temat powołania rządu Tadeusza Mazowieckiego, czy wyborów prezydenckich z 1990 roku). Można by pomyśleć, że wraz ze zmierzchem Polski Ludowej czasopismo odsunęło się od polityki, kładąc największy nacisk na wątki literackie i krajoznawcze.

Istotna transformacja „Płomyczka” stała się widoczna dopiero w 1994 roku. W pierwszym numerze $\mathrm{z}$ tego rocznika redakcja wystosowała do czytelników list ogłaszający nową formułę miesięcznika. Znamienna była już zmiana podtytułu czasopisma z "Miesięcznika dla dziewcząt i chłopców” na „Miesięcznik dziewcząt i chłopców”. W ten sposób zapraszano czytelników do współredagowania „Płomyczka” poprzez inspirowanie wydawnictwa do poruszania pożądanych przez młodzież tematów, ale także dzielenie się własnymi artykułami, opowiadaniami i wierszami, które miały odtąd na stałe zagościć na łamach czasopisma. W liście wyrażono także ambicję, by „Płomyczek” mógł być pomocny podczas lekcji wychowania do życia $\mathrm{w}$ rodzinie, podejmując trudne, kontrowersyjne tematy, także z zakresu wychowania seksualnego. List zakończono obietnicą: „Będziemy rzecznikami Waszych interesów, ale będziemy też nieustannie wskazywali, iż dziś, w dobie tak wielkiej ekspansji wartości materialnych, BYĆ znaczy więcej niż MIÉ́' 25 .

Ten sam rok 1994 roku upłynął na łamach „Płomyczka” pod znakiem pomysłu powołania Partii Dziecka oraz Konwencji Praw Dziecka. To ciekawe, że dopiero trzy lata po ratyfikowaniu konwencji przez Polskę, czasopismo zdecydowało się przybliżyć jej treść i tym samym opowiedzieć się po stronie swoich czytelników. Trzeba jednak przyznać, że sposób w jaki to uczyniło, potwierdziło świeżo uzyskaną wolność światopoglądową naszego kraju. Mianowicie, redakcja pozwoliła sobie na refleksję na temat przestrzegania praw dziecka w naszej ojczyźnie. Napisano wówczas:

(...) w ostatnich latach i państwo zapomniało o uznanej Konwencji Praw Dziecka. Wielkie przemiany polityczne i gospodarcze zepchnęły w cień i ograniczyły prawa dziecka. Zredukowana została liczba miejsc w przedszkolach, zajęcia pozalekcyjne w szkołach. Kolonie i obozy pozostały tylko dla nielicznych. Opłaty za naukę w szkołach średnich uniemożliwiają często dalsze kształcenie ${ }^{26}$.

${ }^{24}$ Por. tekst piosenki Pomożemy odwołujący się do planu sześcioletniego, „Płomyczek” 1950, nr 18, s. 272.

${ }^{25}$ J. Sapa, Drodzy, Młodzi Czytelnicy, "Płomyczek” 1994, nr 1-2, s. 2.

26 J. Sapa, Światecznie bez laurki, „Płomyczek” 1994, nr 6, s. 2. 
Ten krytyczny komentarz pod adresem rządzących był bezprecedensowy w dotychczasowej, ponad 60-letniej historii „Płomyczka”. W 1996 roku redakcja równie otwarcie skrytykowała posłów, którzy odrzucili projekt nowelizacji przepisów Kodeksu rodzinnego i opiekuńczego w celu dostosowania ich do ratyfikowanej Konwencji Praw Dziecka ${ }^{27}$. Zasadę obowiązującej wolności prasy wykorzystano także między innymi przy okazji omawiania niedociągnięć reformy oświaty z 1999 roku $^{28}$, czy wskazywania luk w polskim prawie, skutkujących ludzkimi tragediami ${ }^{29}$.

W 1993 roku senator Maria Łopatkowa wysunęła propozycję powołania Partii Dziecka, w ramach której wytypowani przez dzieci dorośli broniliby w parlamencie interesów najmłodszych. „Płomyczek” podchwycił ten pomysł i zachęcał dzieci do zgłaszania swoich kandydatur ${ }^{30}$. Niestety, inicjatywa Łopatkowej nie odniosła sukcesu, niemniej warto podkreślić, że prezentowane czasopismo opowiedziało się za uczestnictwem dzieci w procesach podejmowania decyzji zarówno w skali "mikro”, jak chociażby wpływ na treść miesięcznika, ale też „makro” - w kwestiach ustawodawczych.
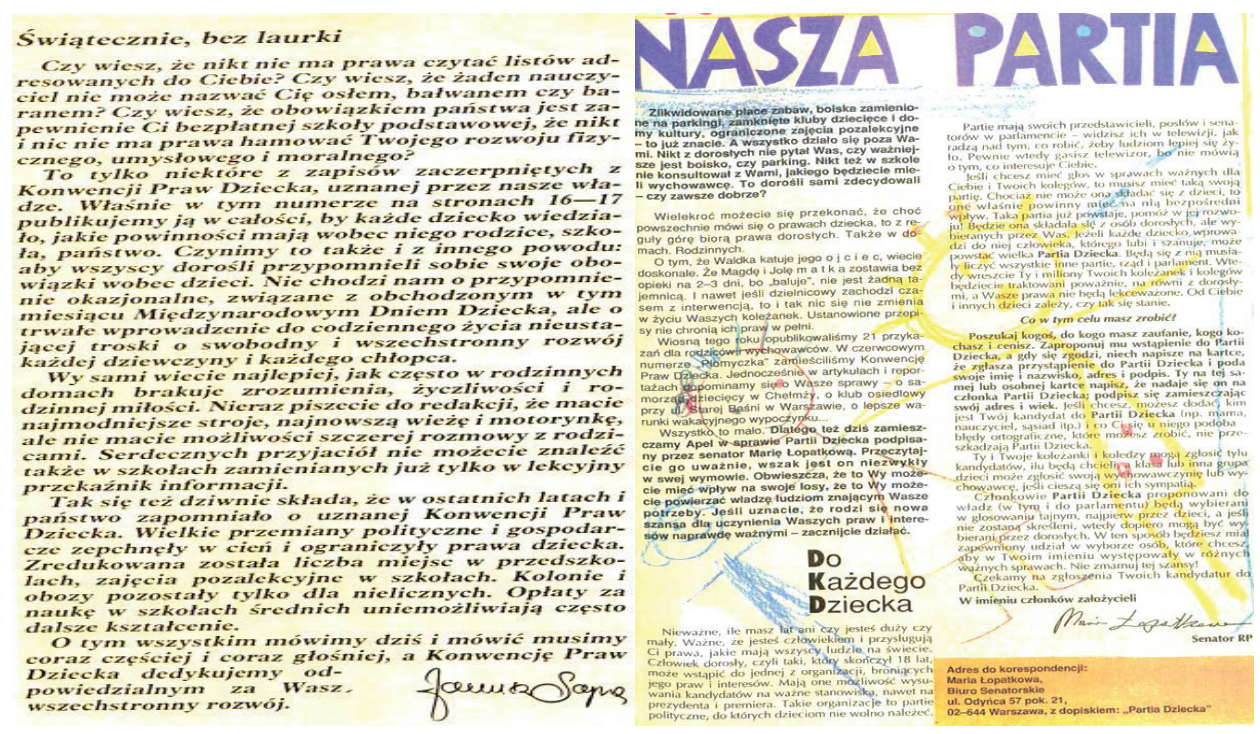

Ryc. 3. List redaktora naczelnego wytykający rządzącym nieprzestrzeganie praw dziecka (fot. 5) oraz artykuł przybliżający inicjatywę M. Łopatkowej - Partię Dziecka (fot. 6)

Źródło: „Płomyczek” 1994, nr 6, s. 2 (fot. 5), „Płomyczek” 1994, nr 9, s. 5 (fot. 6)

\footnotetext{
27 J. Sapa, Dzieci przegrały w Sejmie, „Płomyczek” 1996, nr 2, s. 3.

28 A. Dzięgielewska, Obiecanki - cacanki gimbusy, „Płomyczek” 1999, nr 12, s. 29.

${ }^{29}$ W. Sajan, Paragraf zabija serce, „Płomyczek” 1994, nr 12, s. 4.

${ }^{30}$ Nasza partia, „Płomyczek” 1994, nr 9, s. 5.
} 
„Płomyczek” był również rzecznikiem integracji europejskiej - przybliżał czytelnikom wiedzę na temat Unii Europejskiej, starając się emocjonalnie zaangażować ich w unijne kwestie, na przykład publikując odpowiedzi młodzieży na pytanie "Co zrobiłbym, gdybym został prezydentem Europy?"31. Sposób, w jaki redaktor naczelny, Janusz Sapa, ogłosił wstąpienie Polski w poczet krajów Unii, określiłabym jako radosny, ale i wyważony ${ }^{32}$. Redaktor podzielił się z czytelnikami nie tylko szansami, jakie stają teraz przed Polakami - możliwość decydowania o losach Europy, swobodne podróżowanie i osiedlanie się, nauka na zagranicznych uczelniach, ale i obowiązkami, a także obawami z tym wydarzeniem związanymi. Sapa zaznaczył, że przed naszym krajem stoi teraz wyzwanie wzmocnienia gospodarki, oczyszczenia życia społecznego z nieuczciwości, rozwoju kultury i wzmocnienia tożsamości narodowej. Ostrzegał też młodzież, że kiedy dorosną, przybędzie im konkurentów na rynku pracy. Uważam, że taka retoryka była wyrazem szczerości i partnerskiego stosunku do czytelników.

Tak jak zapowiadano, „Płomyczek” nie stronił od tak zwanych „trudnych tematów". Na jego łamach poruszano między innymi kwestie narkotyków, pracy zarobkowej dzieci, czy aktualnych konfliktów etnicznych. Co zaś się tyczy edukacji seksualnej, to w drugiej połowie lat dziewięćdziesiątych ukazywał się cykl zatytułowany „Kłopoty z dojrzewaniem”, w którym specjalista, podpisujący się jako dr Maciej, odpowiadał na pytania czytelników dotyczące przede wszystkim przeobrażeń fizycznych i psychicznych okresu adolescencji, a także podejmował wątek inicjacji seksualnej, podkreślając psychologiczne następstwa wcześnie podjętego współżycia.

Z analizy "płomyczkowych" numerów wydanych w III Rzeczpospolitej wynika, iż wśród najbardziej cenionych przez redakcję wartości znalazły się: przyjaźń, rodzina, zdrowie, wiedza - drukowane w nich materiały mogły być pomocne na zajęciach szkolnych. W "płomyczkowej” hierarchii wysoko plasował się także patriotyzm. Redakcja często podkreślała, że jej celem jest „wychowywanie w duchu polskiej kultury i tradycji narodowej"33. Sporą grupę tekstów stanowiły poświęcone polskiej historii, literaturze, czy geografii, zdecydowanie dominując ilościowo nad prezentacjami odmiennych kultur i krajów. Warto jednakże podkreślić, iż postawa redaktorów wobec innych państw była życzliwa lub po prostu neutralna, w żaden sposób nie przystając do pogardy i wrogości, jaką kierowano w czasopiśmie z okresu PRL pod adresem Stanów Zjednoczonych i krajów Europy Zachodniej. „Płomyczek” z okresu „wolnej Polski” promował także uczciwość, niesienie pomocy innym

\footnotetext{
31 Gdybym byt prezydentem Europy..., „Płomyczek” 2004, nr 6, s. 3.

32 J. Sapa, Europejski egzamin, „Płomyczek” 2004, nr 4, s. 2.

${ }^{33}$ http://www.plomyczek.amos.waw.pl/ [dostęp: 3.12.2018].
} 
oraz przedsiębiorczość - w specjalnym cyklu przybliżano czytelnikom takie pojęcia ekonomii rynkowej, jak na przykład „wydajność, , „popyt”, ,"eksport”.

Co zaś się tyczy wzorów osobowych promowanych przez czasopismo, to zauważono, że najczęściej prezentowano czytelnikom sylwetki popularnych piosenkarzy i sportowców. Przypominano również postacie z przeszłości: Józefa Piłsudskiego, Fryderyka Chopina, Henryka Sienkiewicza. Można także zauważyć troskę redaktorów o „przywrócenie kobiet historii”, kiedy wspominano o bohaterkach powstania listopadowego - Emilii Plater i Barbarze Bronisławie Czarnowskiej oraz uczestniczce powstania styczniowego Annie Pustowójtównie.

Nie znaleziono natomiast, charakterystycznych dla poprzednich dekad, tekstów wychwalających osoby aktualnie rządzące. Z przeprowadzonych analiz wynika jednak, że kilkakrotnie przybliżano młodzieży działalność i przemyślenia Jana Pawła II oraz księdza Jana Twardowskiego. Miesięcznik powrócił tym samym do tradycji przedwojennych numerów, redagowanych zgodnie z chrześcijańskim światopoglądem. Kwestie religijne w „Płomyczkach" z przełomu XX i XXI wieku pojawiały się okazjonalnie - w okresie Wielkanocy, Świąt Bożego Narodzenia, czy pielgrzymek Jana Pawła II do ojczyny lub rocznic jego pontyfikatu. W tym czasie czasopismo działało zgodnie z zagwarantowaną w Konstytucji zasadą wolności sumienia i religii. Wątki katolickie gościły na jego kartkach zapewne z uwagi na największy procentowy udział katolików w polskim społeczeństwie i ścisłe powiązania katolicyzmu z polską kulturą. Redakcja, jak się wydaje, nie namawiała jednak czytelników do uczestnictwa w określonych praktykach religijnych, ani nie deprecjonowała innych wyznań - na przykład portretując Isaaca Singera, wspomniano przy okazji o judaizmie ${ }^{34}$ - niemniej rzadko pisano o innych, niż chrześcijaństwo, religiach.

\section{Konkluzje}

Reasumując, można stwierdzić, że ukazujący się na przestrzeni trzech okresów historycznych Polski „Płomyczek”, w każdym z nich prezentował inne, zgodne z aktualną sytuacją polityczną, oblicze. Odnosząc się do tytułowej kwestii, dotyczącej wykorzystania pisemka jako narzędzia indoktrynacji, można udzielić niejednoznacznej odpowiedzi, zależnej od okresu, w jakim było ono publikowane. Podążając za słownikową definicją indoktrynacji, trzeba zauważyć, że w przypadku „Płomyczka” można o niej mówić w odniesieniu do numerów z II Rzeczpospolitej i czasów PRL. W tamtych okresach wizje

${ }^{34}$ I.B. Singer, Rozmowa z ojcem i matka, „Płomyczek” 1992, nr 11, s. 14-15. 
rzeczywistości oraz modele wychowania władz i czasopisma były zbieżne, a „Płomyczek” sięgał po takie metody dezinformacji, jak negacja faktów czy rozmycie. Takie zabiegi odpowiadają, wyodrębnionym przez $\mathrm{Ch}$. Tan, kryteriom zawartości i metody, cechującym indoktrynację. Z dużym prawdopodobieństwem można także uznać, że intencje, jakie przyświecały redaktorom czasopisma z okresu II RP i PRL, odpowiadały tym wymienionym przez badaczkę - uśpienie w czytelnikach krytycyzmu i przyjęcie bezzasadnych, fałszywych informacji. Tymczasem, "Płomyczek” wydawany w wolnej, demokratycznej Polsce wychowywał w sposób nie mający nic wspólnego z manipulacją, traktując swych czytelników podmiotowo, stymulując ich refleksyjność oraz priorytetowo ujmując dobro dziecka. Należy wyrazić ubolewanie, że to wspierające rozwój młodych ludzi czasopismo, istny biały kruk pośród nastawionych na zysk i schlebiających gustom większości magazynów przełomu XX i XXI wieku, zostało pozbawione ministerialnych dotacji i tym samym zmuszone do zaprzestania publikacji.

\section{BIBLIOGRAFIA}

Aleksandrzak S., Działalność wydawnicza Zwiąku Nauczycielstwa Polskiego, Przegląd Historyczno-Oświatowy, 1974, 1.

Bober S., Walka o dusze dzieci i młodzieży w pierwszym dwudziestoleciu Polski Ludowej, Lublin 2011.

Brodala M., Propaganda dla najmłodszych w latach 1948-1956. Instrument stalinowskiego wychowania, [w:] Przebudować człowieka. Komunistyczne wysiłki zmiany mentalności, red. M. Kula, Warszawa 2001.

Chomsky N., Chomsky on MisEducation, Lanham 2004.

Gutek G.L., Filozoficzne i ideologiczne podstawy edukacji, Gdańsk 2003.

Indoktrynacja, [w:] Pedagogika. Leksykon PWN, red. B. Milerski, B. Śliwerski, Warszawa 2000.

Jakubiak K., Wychowanie państwowe jako ideologia wychowawcza sanacji, Bydgoszcz 1994.

Magiera E., Wychowanie morskie na łamach "Ptomyczka" i "Płomyka" w Polsce Ludowej, [w:] Oświata, wychowanie i kultura fizyczna w rzeczywistości społeczno-politycznej Polski Ludowej (1945-1989), red. R. Grzybowski, Torun 2004.

Michalska I., Czasopisma Związku Nauczycielstwa Polskiego dla dzieci w okresie Drugiej Rzeczypospolitej, Łódź 1994.

Nowicka-Watrak B., Wychowanie to manipulowanie człowiekiem, Edukacja i Dialog, 2003, 1.

Olszewska B., Literatura na łamach „Płomyczka" (1945-1980), Opole 1996.

Olszewska B., Techniki ideologicznej indoktrynacji w wybranych utworach realizmu socjalistycznego publikowanych w "Płomyczku”, Kwartalnik Opolski, 2008, 2/3.

Podlawska D., Płóciennik I., Nowomowa, [w:] Słownik wiedzy o języku, Bielsko-Biała 2006.

Rogoż M., Czasopisma dla dzieci i młodzieży Instytutu Wydawniczego "Nasza Księgarnia" w latach 1945-1989, Kraków 2009.

Śliwerski B., Program wychowawczy szkoty, Warszawa 2001.

Śniegocki R., Historia. Burzliwy wiek XX, Warszawa 2006.

Tan Ch., Teaching without indoctrination: implications for values education, Rotterdam 2008.

Trzebiatowski K., Szkolnictwo powszechne w Polsce w latach 1918-1932, Wrocław 1970. 


\section{Analizowane materiały}

Artykuł poświęcony zmarłemu B. Bierutowi, „Płomyczek” 1956, nr 14.

Dzięgielewska A., Obiecanki - cacanki gimbusy, „Płomyczek” 1999, nr 12.

Gdybym byt prezydentem Europy..., „Płomyczek” 2004, nr 6.

Nasza partia, „Płomyczek” 1994, nr 9.

Okładka „Płomyczka” 1935, nr 23.

Okładka „Płomyczka” 1950, nr 18.

Polska w żałobie, "Płomyczek” 1935, nr 36.

Pomożemy, „Płomyczek” 1950, nr 18.

Sajan W., Paragraf zabija serce, „Płomyczek” 1994, nr 12.

Sapa J., Drodzy, Młodzi Czytelnicy, „Płomyczek” 1994.

Sapa J., Dzieci przegraty w Sejmie, „Płomyczek” 1996, nr 2.

Sapa J., Europejski egzamin, „Płomyczek” 2004, nr 4.

Sapa J., Świątecznie bez laurki, „Płomyczek” 1994, nr 6.

Singer I.B., Rozmowa z ojcem i matka, „Płomyczek” 1992, nr 11. 